\title{
Genetic differentiation between
} Mediterranean and Atlantic populations of the common prawn Palaemon serratus (Crustacea: Palaemonidae) reveals uncommon phylogeographic break

\author{
RONJA WEISS ${ }^{1}$, ZELTIA TORRECILLA ${ }^{2}$, ENRIQUE GONZÁLEZ-ORTEGÓN ${ }^{3,4}$, ANA M. GONZÁLEZ-TIZÓN ${ }^{2}$, \\ ANDRÉS MARTÍNEZ-LAGE ${ }^{2}$ AND CHRISTOPH D. SCHUBART ${ }^{1}$ \\ ${ }^{1}$ Zoologie \& Evolutionsbiologie, Universität Regensburg, D-93040 Regensburg, Germany, ${ }^{2}$ El Departamento de Biología Celular y \\ Molecular, CICA, Universidade da Coruña, E-15008 A Coruña, Spain, ${ }^{3}$ Instituto Español de Oceanografía, Centro Oceanográfico de \\ Cádiz, Puerto Pesquero, Muelle de Levante s/n, E-11006 Cádiz, Spain, ${ }^{4}$ Instituto de Ciencias Marinas de Andalucía (CSIC), Campus \\ Universitario Río San Pedro, 11519 Puerto Real, Cádiz, Spain
}

\begin{abstract}
The Atlantic-Mediterranean transition zone between the Alborán Sea and the Gulf of Cádiz constitutes the most prominent marine geographic barrier in European waters and includes known phylogeographic breaks such as the Strait of Gibraltar and the Almería-Oran Front. A genetic shift in this area has been previously documented for the European littoral shrimp Palaemon elegans. Here we carried out a phylogeographic analysis with the congeneric and sympatric species Palaemon serratus to test for similar intraspecific genetic differentiation and geographic structure. This littoral prawn is distributed in the Northeastern Atlantic Ocean, the Mediterranean Sea and the Black Sea. We compared DNA sequences from the mitochondrial genes Cox1 and to a lesser extent from $16 \mathrm{~S}$ rRNA of several Atlantic and Mediterranean populations. Furthermore, sequences from the nuclear gene Enolase were included for corroborating differences between Mediterranean and Atlantic individuals. A pronounced genetic differentiation was detected between the Mediterranean and Atlantic populations, amounting to $10.14 \%$ in Cox1 and $2.0 \%$ in $16 \mathrm{~S}$, indicating the occurrence of two independent evolutionary lineages. Interestingly, specimens from the Atlantic Gulf of Cadiz cluster together with the Mediterranean individuals, indicating that a biogeographic barrier appears to be located west of the Strait of Gibraltar.
\end{abstract}

Keywords: Decapoda Caridea, Mediterranean Sea, Atlantic Ocean, Gulf of Cadiz, phylogeography, mtDNA Coxı

Submitted 19 February 2017; accepted 13 March 2017; first published online 8 June 2017

\section{INTRDDUCTIDN}

Recent molecular biodiversity studies increasingly reveal local genetic differentiation in biphasic marine species with a larval dispersal phase (e.g. Mathews, 2006; Galarza et al., 2009; Ragionieri et al., 2009; Fratini et al., 2016). Geographic barriers are the main historical factor determining the biogeography of European marine species, as documented for caridean shrimps (Reuschel et al., 2010; González-Ortegón et al., 2016). The most prominent geographic barrier in European marine waters is the one between the Atlantic Ocean and the Mediterranean Sea. It is located somewhere in between the Alborán Sea and the Gulf of Cádiz, and either the Strait of Gibraltar or the Almería-Oran Front have been postulated to act as the main barrier, as recently revised and discussed (Patarnello et al., 2007; García-Merchán et al., 2012). In recent geological history,

Corresponding author:

C.D. Schubart

Email: Christoph.Schubart@ur.de the shallow Strait of Gibraltar isolated the Mediterranean Sea repeatedly from the Atlantic, caused by sea level regressions, sometimes even resulting in major desiccations (Hsü et al., 1977). These repeated isolations led to a very high level of endemism in the Mediterranean Sea (Hofrichter, 2002), and many marine species show a phylogeographic break among Atlantic and Mediterranean populations (Zane et al., 2000; Patarnello et al., 2007; Luttikhuizen et al., 2008; Deli et al., 2016). The Messinian Salinity Crisis in the late Miocene (around $5.5 \mathrm{Ma}$ ) was probably the most dramatic isolation event (Krijgsman et al., 1999) and ended with the Zanclean Flood, i.e. when Atlantic waters re-flooded the Mediterranean Basin, leading to a re-colonization of the Mediterranean Sea with Atlantic species (García-Castellanos et al., 2009). Even today, the waters between the Strait of Gibraltar and the Almería-Oran Front seem to act as a barrier to gene flow for many marine species, determining the genetic structure and diversity of many European coastal water species.

The shrimp genus Palaemon Weber, 1795 (Crustacea: Decapoda: Caridea) belongs to the large family Palaemonidae Rafinesque, 1815 and includes many important 
representatives from coastal waters all over the world. Recently, important systematic and taxonomic changes were postulated for this family, summarized in the review by De Grave \& Ashelby (2013), with the consequence that the genera Palaemonetes Heller, 1869, Exopalaemon Holthuis, 1950 and Coutierella Sollaud, 1914 were synonymized and re-arranged within the genus Palaemon that now contains 83 species (for the most recent phylogeny see Carvalho et al., 2016). Morphological distinction within this genus is partly difficult, because only small differences serve as identification criteria, as for example the upper antennular flagellum or the denticulation of the rostrum (González-Ortegón \& Cuesta, 2006). This often results in wrongly classified species within the genus Palaemon. For example, Palaemon garciacid Zariquiey Álvarez, 1968 turned out to be a synonym of Palaemon longirostris Milne-Edwards, 1837 (Cuesta et al., 2012; Cartaxana, 2015). Also the existence of cryptic species is discussed for this genus, since Reuschel et al. (2010) gave evidence for differentiation along the AtlanticMediterranean barrier within Palaemon elegans Rathke, 1837 and the possible existence of a cryptic species within the Mediterranean Sea. Thus, it seems worthwhile to use genetic techniques to study phylogeographic relationships between Atlantic-Mediterranean populations of other coastal species of Palaemon and to help redefine the morphological classification in this taxonomic group. It is of particular interest to focus on species living in both the Atlantic Ocean and the Mediterranean Sea, to determine if similar differentiation patterns may be revealed as in P. elegans. In Europe, six marine and/or estuarine species (including the recently introduced P. macrodactylus Rathbun, 1902 (see González-Ortegón et al., 2007; Ashelby et al., 2013)) and four fresh to brackish water species of Palaemon can be found (Cuesta et al., 2012). The former ones include the widespread and commercially exploited species Palaemon serratus (Pennant, 1777), also known as the common prawn. It could make an interesting study object regarding phylogeographic analyses, as a recent published record indicated that a single Mediterranean specimen from the Turkish coast may be distinct from its Atlantic counterparts (Bilgin et al., 2014).

Palaemon serratus lives in rocky crevices along the European and North African coastlines in shallow waters up to a depth of $40 \mathrm{~m}$. Its distribution area ranges from Scotland and Denmark to Mauritania and it is common in the Atlantic Ocean, with occasional records in the Mediterranean Sea, and the Black Sea (Lagardère, 1971; d'Udekem d'Acoz, 1999). Adult individuals have a total length of 90-110 $\mathrm{mm}$ and the cephalothorax and abdomen are transparent with a dark reddish-brown striped pattern which can vary widely between different regions or habitats (Carlisle, 1955; González-Ortegón \& Cuesta, 2006). Larval development is linked to initial larval body mass and female body size and can be modified by environmental conditions experienced by the larvae (Reeve, 1969; González-Ortegón \& Giménez, 2014).

There is an important commercial fishery on P. serratus, especially around the British Isles, France and northern Spain, and the high commercial value could possibly lead to overfishing, as already expressed by Fahy et al. (2006). Even though the latter study only evaluated the fisheries around Ireland, the same problems could also occur elsewhere. Currently, baseline monitoring data are gathered in the UK and Ireland to ascertain the stock status and population trends and to identify possible problems caused by the fishery exploitation (Haig et al., 2014). Although this species was proposed as suitable for cultivation (Reeve, 1968; Rodríguez, 1981), further studies about its ecology and husbandry conditions are necessary to take this step. For this endeavour, basic knowledge on the natural genetic diversity and the phylogeography of this species will be critically important.

This study thus focused on the genetic differentiation among various populations of $P$. serratus along European coastlines. DNA sequences for the mitochondrial gene Cox 1 were analysed. To confirm the obtained results additional sequences of the more conserved mitochondrial $16 \mathrm{~S}$ rRNA and the nuclear gene Enolase were included. Coxi and $16 \mathrm{~S}$ rRNA have been shown to be suitable marker genes for DNA barcoding in crustaceans (Schubart et al., 2000; Lefébure et al., 2006; Costa et al., 2007) and also within the Palaemonidae (Reuschel et al., 2010; Cartaxana, 2015). Special attention is paid to the possible divergence among Atlantic and Mediterranean populations, as previously reported for the closely related prawn $P$. elegans (see Reuschel et al., 2010).

\section{MATERIALS ANDMETHODS}

Specimens of Palaemon serratus used for the analysis originated from the authors' collections and were stored in $70-$ 95\% ethanol. Most individuals were sampled by hand with the aid of a dip net. Sampling localities, coordinates and number of sequences for each available population of $P$. serratus are shown in Figure 1 and Table 1. For some populations, only the locality was given and the coordinates were estimated. DNA-extractions were performed following either the Puregene Method (from Gentra Systems: Minneapolis, MN55447, USA) or the Realpure - Spin Kit 250 Extract (from Durviz - Gentaur: Brussels, Belgium).

Two different mitochondrial DNA gene fragments were amplified by means of PCR reactions: the mitochondrial gene Cox 1 encoding subunit 1 of the cytochrome $c$ oxidase gene that is especially suitable for intraspecific comparisons and used as the biological barcoding gene (e.g. Costa et al., 2007) ( $\mathrm{N}=67$ sequences). In addition, one individual of each of five Atlantic populations and four individuals of Mediterranean populations were analysed for variation of the more conserved $16 \mathrm{~S}$ rRNA gene, transcribed to the structural rRNA of the large subunit $16 S$ of mitochondrial ribosome. The only available $16 S$-sequence in GenBank (JQ042291) was downloaded and added to the analysis, allowing comparison of a total of 10 sequences. In addition, the nuclear gene Enolase, better suited for interspecific comparisons (e.g. Ip et al., 2015), was amplified for some of the Mediterranean and Atlantic populations ( $\mathrm{N}=26$ sequences).

For both mitochondrial genes, different primer combinations were used. For Cox 1 , a few long fragments of 1276 basepairs (bp) were amplified with primers COL6 or COL6a and $\mathrm{COH} 1 \mathrm{~b}$. This was not possible for the Mediterranean individuals, so a shorter fragment was amplified using the primers $\mathrm{COL}_{1} \mathrm{Pe}$ and $\mathrm{COH}_{1} \mathrm{~b}(63 \mathrm{op})$. For the amplification of the $16 S$ rRNA gene, the forward primer $16 \mathrm{~L}_{2} 9$ and the reverse primer 1472 were used $(\sim 580 \mathrm{bp})$. The nuclear gene Enolase was amplified using the primer combination ENEA1 and ENES1 (409 bp). All primer sequences and the corresponding references are listed in Table 2. 


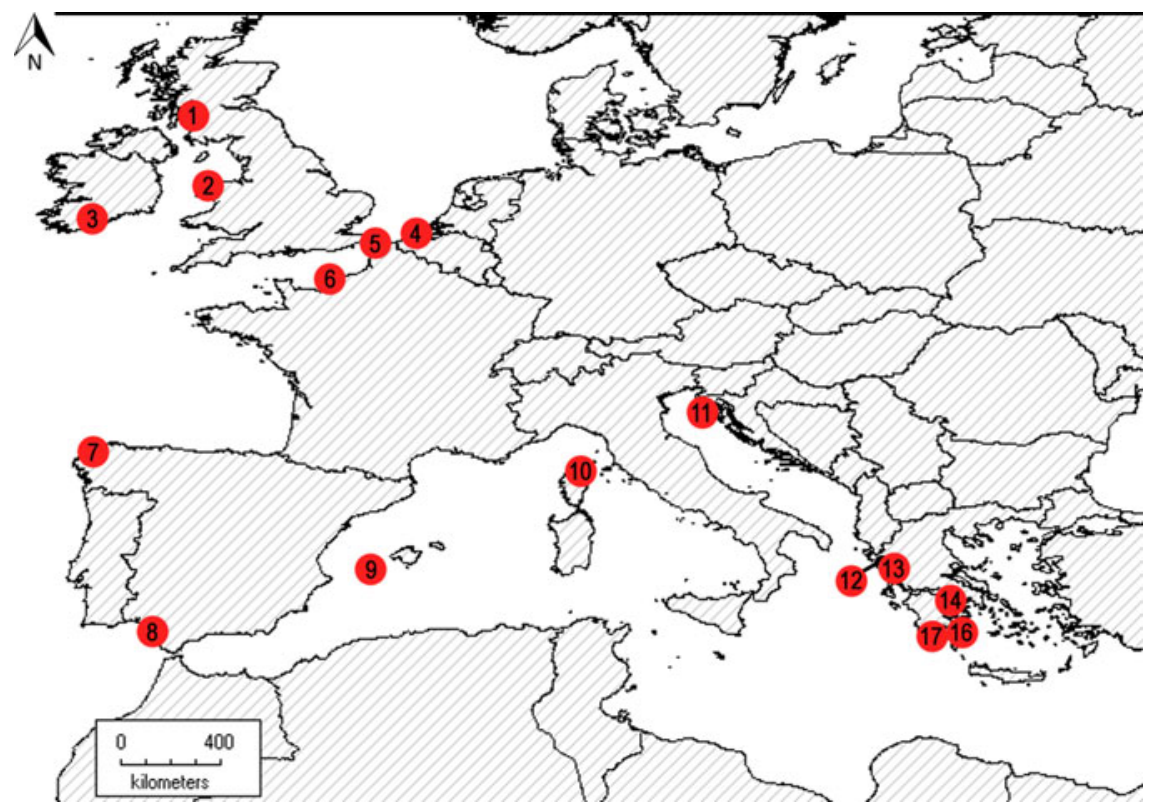

Fig. 1. Sampling localities of Palaemon serratus (Pennant, 1777). The locality numbers correspond to the code numbers in Table 1.

PCR reactions were run in a total volume of $25 \mu$ l with different protocols optimized for the respective Taq polymerase (Fermentas Taq, Promega GoTaq or Roche Taq). The temperature profile of the PCR for all three genes consisted of an initial denaturation step at $94^{\circ} \mathrm{C}$ for $4 \mathrm{~min}$, followed by 35-40 cycles and a final elongation step at $72^{\circ} \mathrm{C}$ for $5^{-}$ $10 \mathrm{~min}$. The cycle program included denaturation at $95^{\circ} \mathrm{C}$ for $45 \mathrm{~s}$, annealing at $52^{\circ} \mathrm{C}$ for the primer combination COL6 or $\mathrm{COL} 6 \mathrm{a} / \mathrm{COH} 1 \mathrm{~b}, 48^{\circ} \mathrm{C}$ for all other mitochondrial gene combinations, and $50^{\circ} \mathrm{C}$ for Enolase for $45-60 \mathrm{~s}$, and elongation at $72^{\circ} \mathrm{C}$ for 60 (short fragments) or 90 (long fragments) seconds. In a few difficult cases, the annealing temperature was decreased to $45^{\circ} \mathrm{C}$ to obtain useable PCR products.

Most of the long fragments of the Coxi gene were sequenced in both directions, while the short fragments were only sequenced with $\mathrm{COH} 1 \mathrm{~b}$. The $16 \mathrm{~S}$ rRNA fragments were sequenced with $16 \mathrm{~L} 29$ and the Enolase fragments with ENEA1. Sanger sequencing took place at the Laboratory of Molecular Biology, SAI (Servicios de Apoyo a la Investigación; University of A Coruña, Spain) or was outsourced to Macrogen Europe (the Netherlands). Sequence chromatograms were proofread using Chromas Lite version 2.1.1 (Technelysium Pty Ltd) and edited manually, if necessary. All sequences were aligned with BioEdit version 7.2.0 (Hall, 1999) using the ClustalW algorithm (Thompson et al., 1994) and, if necessary, adjusted manually. Five different alignments were created, three with the Coxi sequences, depending on the primer combinations and sequence length, and one in each case for the $16 \mathrm{~S}$ and the Enolase datasets. No ambiguities were encountered during the alignment

Table 1. Coordinates and number of individuals of the studied populations of Palaemon serratus from west to east.

\begin{tabular}{|c|c|c|c|c|c|c|c|c|}
\hline \multirow[b]{2}{*}{ Code (Fig. 1) } & \multirow[b]{2}{*}{ Population } & \multirow[b]{2}{*}{ Latitude } & \multirow[b]{2}{*}{ Longitude } & \multirow[b]{2}{*}{ Date } & \multirow[b]{2}{*}{$\mathbf{N}$} & \multicolumn{3}{|c|}{ Sequences } \\
\hline & & & & & & $\operatorname{Cox} 1$ & $16 S$ & Enolase \\
\hline 3 & Cork (Ireland, A) & 51.9 & -8.483333 & August 2012 & 1 & - & 1 & - \\
\hline 7 & Artabro Gulf (Spain, A) & $43 \cdot 366667$ & -8.466667 & October 2012 & 15 & 12 & 1 & - \\
\hline 8 & Guadalquivir Estuary (Spain, A) & 36.783333 & -6.366667 & August 2012 & 21 & 14 & 1 & 10 \\
\hline 1 & Millport (UK: Scotland, A) & 55.749917 & -4.927883 & November 2003 & 1 & - & - & 1 \\
\hline 2 & Anglesey (UK: Wales, A) & 53.133333 & -4.283333 & January 2012 & 9 & 7 & 1 & - \\
\hline 6 & Saint-Jouin-Bruneval (France, A) & 49.645283 & 0.1525 & August 2012 & 10 & 7 & - & 5 \\
\hline 9 & Cala Nova (Spain: Ibiza, M) & 39.007595 & 1.581657 & October 2011 & 2 & 2 & - & - \\
\hline 9 & Cala Llenya (Spain: Ibiza, M) & 39.015299 & 1.587782 & October 2009 & 11 & 10 & 1 & 1 \\
\hline 5 & Calais (France, A) & 50.966667 & 1.80 & September 2012 & 1 & - & 1 & - \\
\hline 4 & Duinbergen (Belgium, A) & 51.35 & 3.25 & October 2012 & 1 & 1 & - & - \\
\hline 10 & Marine de Farinole (France, M) & 42.729274 & 9.339269 & June 2003 & 1 & 1 & 1 & 1 \\
\hline 11 & Pula (Croatia, M) & 44.860903 & 13.81284 & September 2004 & 1 & 1 & 1 & 1 \\
\hline 12 & Acheron Estuary (Greece, M) & 39.236111 & 20.479722 & July 1993 & 2 & 2 & - & 2 \\
\hline 13 & Ligia (Greece, M) & 39.154657 & 20.563746 & September 2003 & 1 & 1 & 1 & - \\
\hline 17 & Githion (Greece, M) & 36.791944 & 22.596389 & July 1986 & 3 & 3 & - & 3 \\
\hline 14 & Nafplio (Greece, M) & 37.547222 & 22.818056 & December 2013 & 1 & 1 & - & 1 \\
\hline 16 & Limin Ieraka (Greece, M) & 36.785833 & 23.0825 & July 1986 & 1 & 1 & - & 1 \\
\hline
\end{tabular}

A, Atlantic Ocean; M, Mediterranean Sea. 
Table 2. DNA primer sequences and corresponding references.

\begin{tabular}{|c|c|c|c|}
\hline Primer & Gene & Sequence $5^{\prime}-3^{\prime}$ & Reference \\
\hline COL6 & $\operatorname{Cox} 1$ & TYT CHA CAA AYC ATA AAG AYA TYG G & Schubart (2009) \\
\hline COL6a & $\operatorname{Cox} 1$ & TCW ACA AAT CAT AAA GAY ATT GG & Schubart (2009) \\
\hline $\mathrm{COL}_{1} \mathrm{Pe}$ & $\operatorname{Cox} 1$ & TAC YTC RTT CTT TGA TCC TGC & New \\
\hline COLib & $\operatorname{Cox} 1$ & CCW GCT GGD GGW GGD GAY CC & Schubart (2009) \\
\hline $\mathrm{COH} 1 \mathrm{~b}$ & $\operatorname{Cox} 1$ & TGT ATA RGC RTC TGG RTA RTC & Schubart (2009) \\
\hline $16 \mathrm{~L} 29$ & $16 S$ & YGC CTG TTT ATC AAA AAC AT & Schubart et al. (2001) \\
\hline 1472 & $16 S$ & AGA TAG AAA CCA ACC TGG & Crandall \& Fitzpatrick (1996) \\
\hline ENEA1 & Enolase & CAG CAA TCA ATG TCA TCA AYG GWG G & Tsang et al. (2014) \\
\hline ENES $_{1}$ & Enolase & ACT TGG TCA AAT GGR TCY TCA AT & Tsang et al. (2014) \\
\hline
\end{tabular}

process. Before building the parsimony network, the alignments were cropped manually to the same length and short sequences were eliminated. All new DNA sequences (all haplotypes in case of Cox1) were submitted to the European Nucleotide Archive (ENA as part of GenBank) and have been assigned accession numbers $\mathrm{LT}_{717247}$ to $\mathrm{LT} 717310$ Alignments were converted from FASTA to PHYLIP format with FaBox version 1.41 (URL 1). Finally, five networks were constructed with the software TCS version 1.21 (Clement et al., 2000) based on the single alignments. In the three Coxi networks, the maximum connection steps had to be specified manually (65-130 steps) in order to allow the haplogroups to be connected, while in the Enolase network a $95 \%$ and in the $16 \mathrm{~S}$ network a $94 \%$ connection limit between the different genotypes were used. Nucleotide and haplotype diversities were calculated with the software DnaSP version 5.10.01 (Librado \& Rozas, 2009) for six different populations (only populations with more than two individuals were included). A permutation test was performed with 10,000 replicates. Also a mismatch analysis of sequences was carried out with DnaSP version 5.0 for the Cox 1 and for the $16 S$ alignments containing Mediterranean individuals. A constant population size was chosen as the model for expected values. Finally, an analysis of molecular variance (AMOVA) was carried out for two of the populations of the Mediterranean (with more than eight individuals) and the population of Guadalquivir using the software DnaSP version 5.0

\section{RESULTS}

For many of the long fragments of Coxi, clean reads were only obtained for one direction. Therefore, sequences were subdivided into three length groups of which three different alignments and three different parsimony networks were constructed. The first alignment consists of 17 consensus sequences of forward and reverse reads of the long primer combination, resulting in $1199 \mathrm{bp}$. The second alignment contains only the sequences read with the forward primers COL6 or COL6a (26 sequences, $811 \mathrm{bp}$ ) and the third alignment the ones read with the reverse primer $\mathrm{COH} 1 \mathrm{~b}$ ( 58 sequences, $611 \mathrm{bp}$ ). Since all three parsimony networks show similar distribution patterns, only the one with most individuals, i.e. the one sequenced with the primer $\mathrm{COH}_{1} \mathrm{~b}$, is shown (Figure 2). The other two can be found in the Supplementary material (Appendices 1-2). For the graphic presentation of the networks, the two localities of Ibiza (Cala Llenya and Cala Nova) were summarized as one population, since they are geographically very close to each other and there were no important differences in their sequences. The same approach was used for the different sites in Greece.

The maximum parsimony network based on the alignment of the $\mathrm{COH} 1 \mathrm{~b}$ sequences (Figure 2) shows a clearcut dissociation between the Mediterranean populations (including the Guadalquivir Estuary) and the more western Atlantic populations. Sequences from the Guadalquivir Estuary are recovered as four haplotypes, of which haplotype A with 10 individuals holds a central position. Interestingly, the sequences of Guadalquivir Estuary do not share haplotypes with the Mediterranean populations, despite being closely related. Consequently, the Mediterranean populations have their own central haplotype B found in 12 individuals. The Atlantic haplotype closest to the ones of the Guadalquivir Estuary is separated by 62 mutation steps (equivalent to $10.14 \%$ of the $\mathrm{COH} 1 \mathrm{~b}$ alignment length) and belongs to the population of Anglesey. In contrast to the Mediterranean populations and the one of the Guadalquivir Estuary, all the Atlantic populations are mixed and scattered with no recognizable central haplotype. Haplotype and nucleotide diversities were only calculated for the six populations with more than two individuals listed in Table 3. These values can only be compared conditionally, because the number of sequences of each population differs. The population of the Guadalquivir Estuary shows the lowest haplotype diversity with 0.49451 , followed by the individuals of Greece, Ibiza and then Anglesey, while Saint-Jouin-Bruneval and Artabro Gulf with 1.0 each have the highest values. The highest nucleotide diversity is also found in the population of Saint-Jouin-Bruneval, followed by Anglesey and the population of Artabro Gulf and then Ibiza and Greece. The lowest nucleotide diversity was found in the population of the Guadalquivir Estuary with 0.0009 .

For the AMOVA, we also used the COH1b-alignment of the Coxi gene, since it contains most sequences. Eight individuals of the different sites in Greece, 12 individuals of the two populations of Ibiza and 14 individuals of the population of Guadalquivir Estuary were compared. Between Ibiza and Greece, a $\Phi_{\mathrm{ST}}$ value of $0.04562(P=0.1)$ indicates the high level of panmixia between these populations of the Mediterranean Sea. In contrast, the $\Phi_{\mathrm{ST}}$ values of the pairwise differences between Ibiza and the Guadalquivir Estuary (0.62084) and Greece and the Guadalquivir Estuary (0.68065) are highly significant $(P<0.01)$. They demonstrate that there is restricted gene flow across the Strait of Gibraltar, despite the genetic similarity between the Guadalquivir and Mediterranean populations.

To confirm the results of the Coxi gene, a small network was constructed with 10 sequences of the $16 S \mathrm{mtDNA}$ gene 

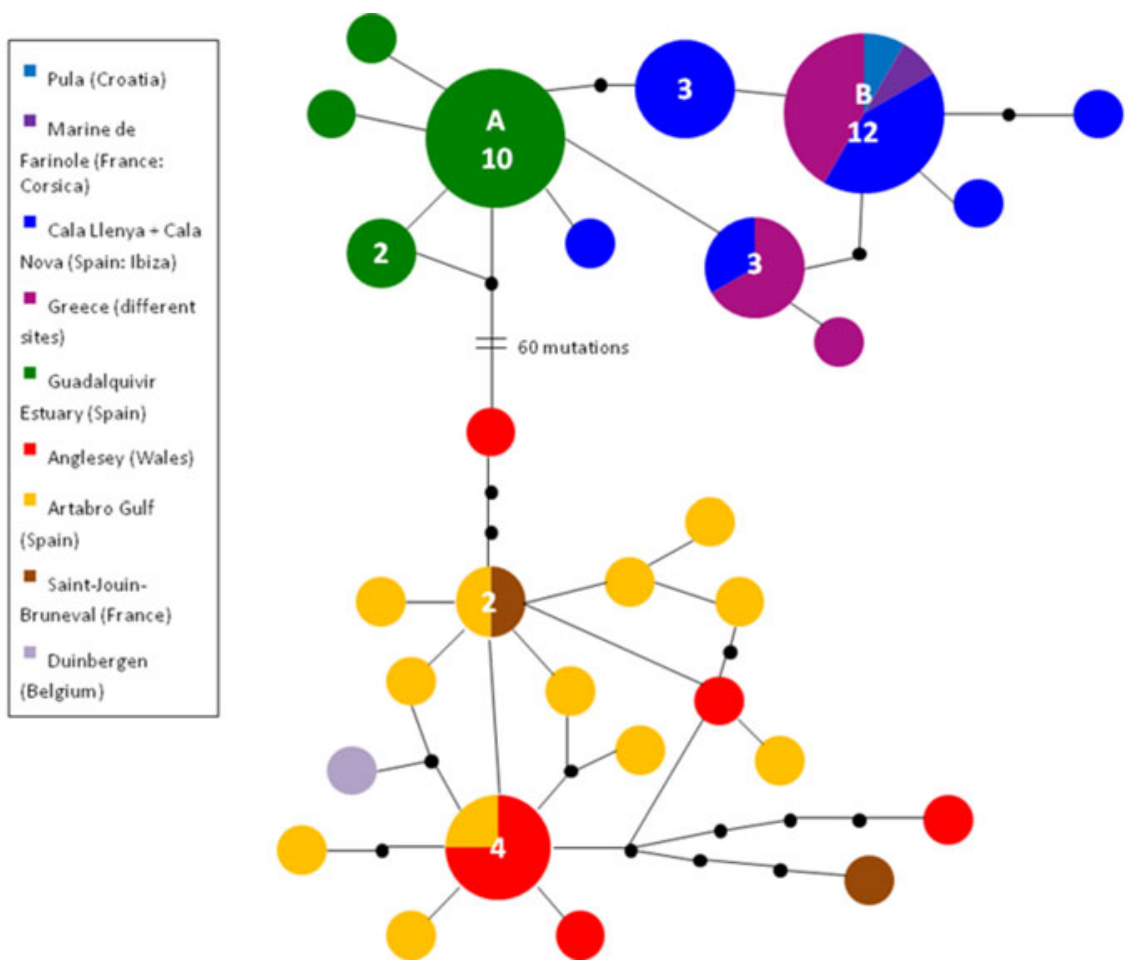

Fig. 2. Maximum parsimony network of Cox 1 mtDNA (COH1b alignment) of Palaemon serratus, constructed with TCS version 1.21 and a connection limit of 65 steps, based on an alignment of 58 sequences ( 611 base pairs). The numbers within the circles correspond to the number of individuals represented by that haplotype (circles without a number represent single individuals). Black spots represent missing haplotypes.

Table 3. Estimates of haplotype and nucleotide diversities of Palaemon serratus, based on the COH1b alignment of the Cox 1 gene with 611 base pairs. Calculated with DnaSP version 5.10.01. Only populations with more than two individuals were included. Permutation test with 10,00o replicates.

\begin{tabular}{lcccc}
\hline Population & Number of sequences & Number of haplotypes & Haplotype diversity & Nucleotide diversity \\
\hline Saint-Jouin-Bruneval (F) & 7 & 7 & 1 & 0.00834 \\
Guadalquivir Est. (Spain) & 14 & 4 & 0.49451 & 0.0009 \\
Artabro Gulf (Spain) & 12 & 12 & 1 & 0.85714 \\
Anglesey (Wales) & 7 & 5 & 0.60714 & 0.0053 \\
Greece & 8 & 3 & 0.80303 & 0.00216 \\
Ibiza (Spain) & 12 & 6 & 0.00288 \\
\hline
\end{tabular}

based on an alignment of 499 basepairs (Figure 3). It consists of four different haplotypes. One of these haplotypes represents three Mediterranean individuals, while the fourth Mediterranean individual only differs in one position. Two individuals of the Gulf of Cádiz population directly west of the Strait of Gibraltar (Cádiz and Guadalquivir Estuary) are also separated from the larger Mediterranean haplotype by one mutational step. In contrast, the fourth haplotype is separated from all others by at least 10 mutational steps (equivalent to 2.0\%) and is found in four individuals of the other Atlantic populations (one of each location from Artabro Gulf, Calais, Cork and Anglesey). Therefore, the $16 \mathrm{~S}$ network confirms the structure of the Coxi network.

The mismatch analyses for both the $\mathrm{COH} 1 \mathrm{~b}$ sequences of Cox 1 mtDNA and 165 rRNA show a bimodal distribution, i.e. two separate peaks, in the frequency of pairwise differences among haplotypes (Figure 4). This reflects the fact that the haplotypes are either very close to each other (within Atlantic and Mediterranean) or more distantly related (between Atlantic and Mediterranean). In Coxi mtDNA, haplotypes are either separated by not more than nine or between 62-71 mutational steps, whereas in $16 \mathrm{~S}$ mtDNA there are either up to two or between 10 and 11 mutational steps. In both cases, the observed frequency (dashed line) did not correspond to the expected values for a constant population size (solid line).

An independent nuclear marker was applied as third evidence and to test for possible ongoing speciation: The nuclear gene Enolase was sequenced from 26 individuals, resulting in an alignment with a length of $409 \mathrm{bp}$. It includes only two parsimony-informative sites that consistently separate two genotypes. The corresponding maximum parsimony network can be found in Figure 5. Ten individuals originating from Croatia, Greece, Ibiza (Spain) and Corsica (France) and 10 from the population of the Guadalquivir Estuary share one genotype, whereas the second genotype is found in five individuals of the Atlantic coast of France and one specimen from Scotland. Therefore, a clean split is confirmed between the Mediterranean plus the Gulf of Cádiz sequences and the more northern Atlantic populations. 


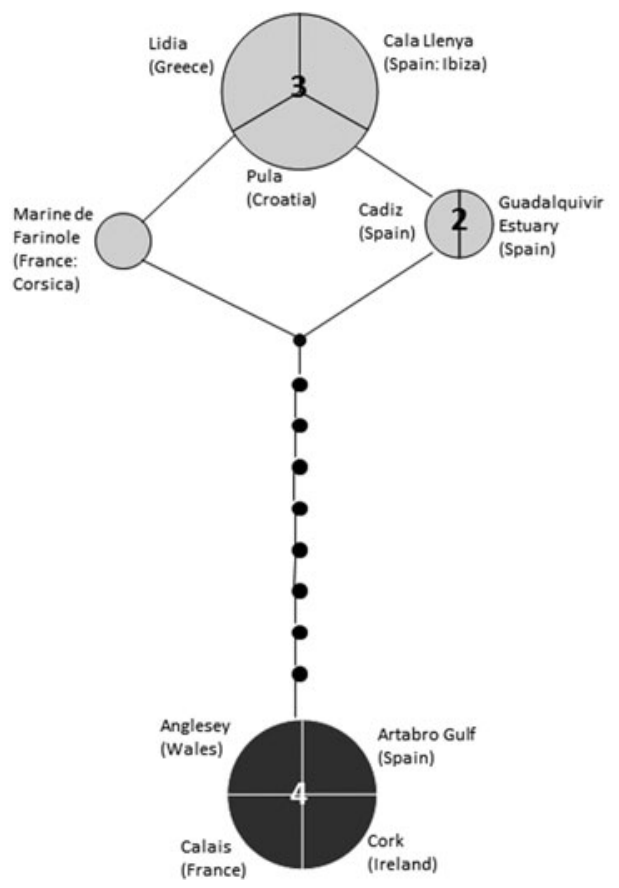

Fig. 3. Maximum parsimony network of $16 \mathrm{~S} \mathrm{mtDNA}$ of Palaemon serratus, constructed with TCS version 1.21 and a connection limit of $94 \%$, based on an alignment of 10 sequences (499 base pairs). The number within the circles correspond to the number of individuals represented by that haplotype (circles without a number represent single individuals). Black spots represent missing haplotypes.

\section{DISCUSSION}

Results of three analysed genes (Coxi mtDNA, 165 rRNA and Enolase nuDNA) show genetic differentiation among the populations of Palaemon serratus in the Mediterranean Sea, the Gulf of Cádiz and the Atlantic Ocean. The individuals of the first two areas are closely related and will henceforth be termed the Mediterranean lineage (ML) which thus includes the populations from the Guadalquivir Estuary and the Mediterranean populations. A sequence from GenBank (JQ042291) corresponding to the $16 \mathrm{~S} \mathrm{mtDNA}$ of an individual from Cádiz confirms that populations from the Gulf of Cádiz are more closely related to Mediterranean populations than to other Atlantic ones. The second lineage, henceforth called the Atlantic lineage (AL), contains all the other Atlantic populations included in this study. The $16 S$ network consists of three different haplotypes in the ML and only one haplotype in the $\mathrm{AL}$, while all three Coxi networks have a smaller number of haplotypes in the ML than in the AL. This can be due to the fact that only one individual per population was used for the $16 \mathrm{~S}$ analysis, so that most likely not all occurring haplotypes are represented in the network. In the Enolase alignment, only two different genotypes can be found, corresponding to ML and AL and separating these in the same fashion as the mitochondrial genes.

The Cox 1 haplotypes of the populations of the Mediterranean are linked tightly, and while the Greek individuals show a moderate haplotype diversity $\left(h_{d}=0.60714\right)$, the individuals of the populations of Ibiza are quite heterogeneous $\left(h_{d}=0.80303\right)$ This suggests that the Mediterranean stocks represent a healthy and stable system, with relatively high gene flow among the sampled populations. Nevertheless, this should be
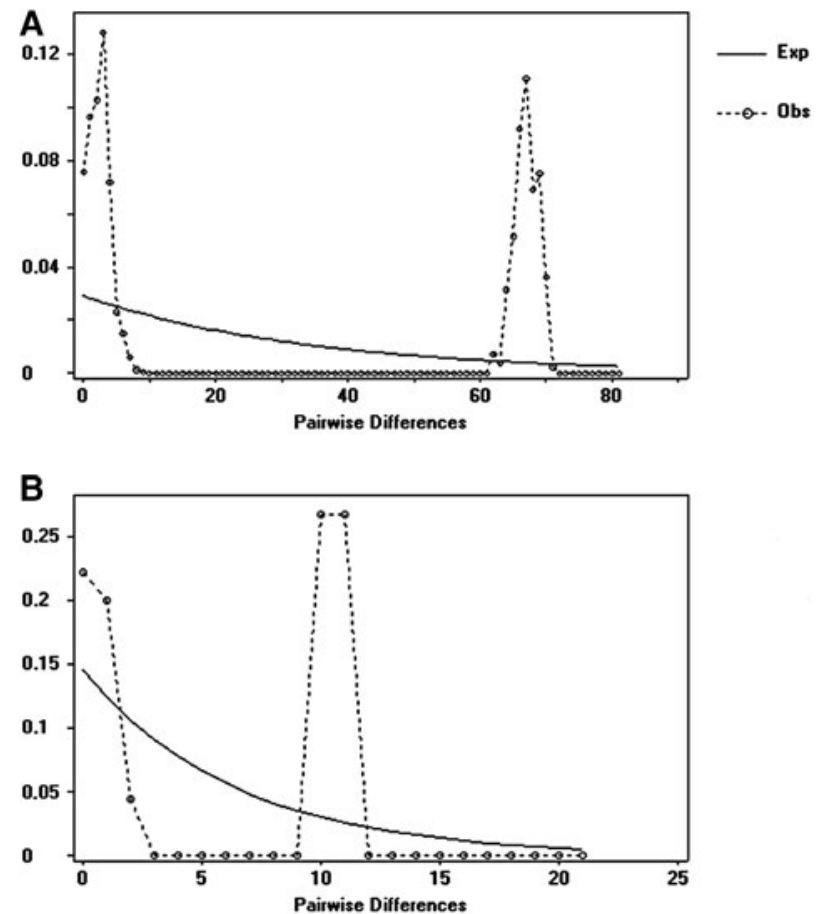

Fig. 4. Mismatch distribution of pairwise differences in two mitochondrial genes of Palaemon serratus. Calculated with DnaSP version 5.10.01. The dashed lines show the observed, the solid lines the expected frequencies within a constant population size. (A) Coxi mtDNA (COH1b alignment with 58 sequences, 611 base pairs). (B) $16 \mathrm{~S}$ mtDNA (10 sequences, 499 base pairs)

tested with more individuals and more populations, since only two Mediterranean populations were used for the analysis of haplotype and nucleotide diversities in this study.

The specimens of the Guadalquivir Estuary form a very homogeneous clade, with only a few haplotypes $\left(h_{d}=\right.$ $0.49451)$ being very close to each other $\left(n_{d}=0.0009\right)$. This can be best explained by a founder effect, i.e. a new population founded by only a few individuals and therefore with low genetic variety. The proximity of some Coxi haplotypes from Ibiza to the Guadalquivir haplotype $A$ suggests a relatively recent colonization from the western Mediterranean. Another possible explanation would be reduced gene flow to and from the Guadalquivir population, because of its geographically marginal position, compared with a population that is located in the centre of the range of a genetic lineage. In any case, current gene flow of the population from the Guadalquivir Estuary with the Mediterranean populations seems limited.

The fact that the population of the Guadalquivir Estuary nevertheless belongs to the ML raises the question why it groups together with Mediterranean populations instead of Atlantic ones. Most other studies of species with a genetic separation of the Atlantic and the Mediterranean populations reveal the opposite scenario: They show an extension of the Atlantic genotypes into the Alborán Sea which is the westernmost part of the Mediterranean Sea. This is for example the case in the closely related prawn Palaemon elegans (see Reuschel et al., 2010) as well as in many other marine species, e.g. the scallops Pecten jacobeus and P. maximus (see Ríos et al., 2002) or the euphausiid Meganyctiphanes norvegica (see Zane et al., 200o). This extension of Atlantic 


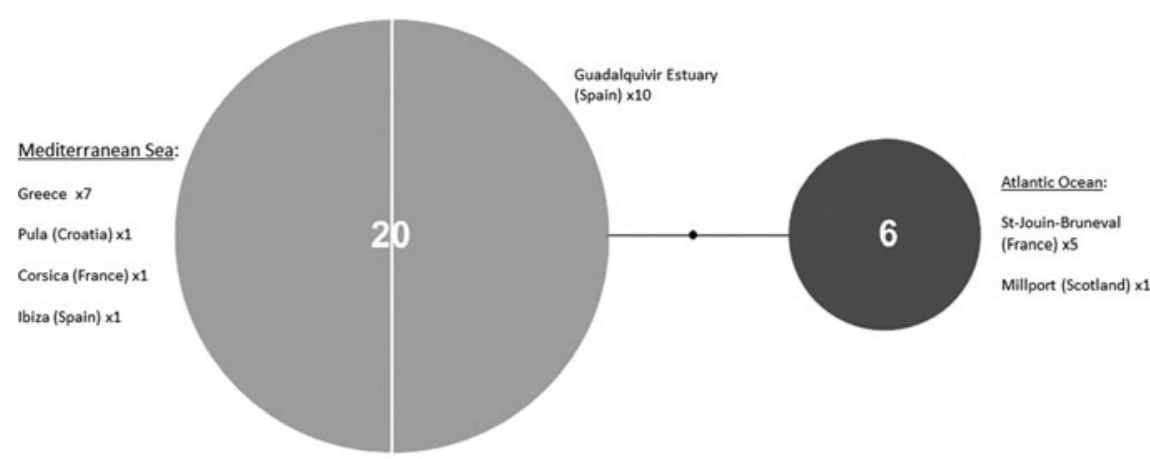

Fig. 5. Maximum parsimony network of Enolase nuDNA of Palaemon serratus, constructed with TCS version 1.21 and a connection limit of $95 \%$, based on an alignment of 26 sequences (409 base pairs). The numbers within the circles correspond to the number of individuals represented by that genotype. Black spot represents missing genotype.

genotypes into the Mediterranean Sea has been explained by the intrusion of Atlantic waters into the Alborán Sea, where they circulate as two gyres, so that the Almería-Oran Front often represents the real hydrographic boundary of Atlantic and Mediterranean surface waters (Tintoré et al., 1988), rather than the Strait of Gibraltar itself. However, in a recent study on several crustacean species, the role of the Strait of Gibraltar as a gene flow barrier compared with the one of the Almería-Oran Front has been emphasized (García-Merchán et al., 2012).

Palaemon serratus is not the only species in which populations of the Guadalquivir Estuary differ genetically from other Atlantic populations, as this was also reported in the mysid Neomysis integer (see Remerie et al., 2009). It remains unknown, when Mediterranean P. serratus may have migrated from the Mediterranean Sea through the Strait of Gibraltar and settled in the Gulf of Cádiz. Furthermore, we do not know if they replaced 'typical' Atlantic P. serratus which theoretically should be better adapted to the local conditions, like temperature and tides, in the Gulf of Cádiz. Alternatively, it is conceivable that the Gulf of Cádiz population may have diverged from Atlantic stocks independently and gave rise to the Mediterranean populations with the flooding of the Mediterranean Basin. Hence, more detailed studies about the dispersal and ecology of $P$. serratus, especially in the area west and east of the Strait of Gibraltar, are necessary to reconstruct how the extension of Mediterranean haplotypes into the Atlantic Ocean took place. A human introduction can be excluded, because the haplotypes from the Guadalquivir Estuary of both mitochondrial genes have so far not been sampled in the Mediterranean Sea and thus appear to be endemic. It remains to be solved, where the contact zone with the other Atlantic populations is, and if there is genetic mixing. One possible explanation for endemic genotypes could be the fact that the population of the Guadalquivir Estuary belongs to the most important nursery area in the Gulf of Cádiz, favouring the reproduction and/or the settlement of local individuals (González-Ortegón et al., 2015) and probably a more estuarine genotype. Further investigations of different populations along the coastline of Andalusia to Portugal are necessary to define the exact border between AL and the haplotypes of the Gulf of Cádiz, and to determine what induces the biogeographic break within the Atlantic Ocean.

The populations of AL are genetically very diverse with 18 different haplotypes in the $\mathrm{COH}_{1} \mathrm{~b}$ network (Figure 2), and all tested populations show very high haplotype and nucleotide diversities. According to the coalescent theory of Kingman (1982), high genetic diversity leads to the conclusion that the corresponding species is presumably of a great age (the higher the diversification the longer the required time span to develop this diversity). This provides evidence that the Atlantic stock of Palaemon serratus represents a very stable and healthy system, which has probably existed for a long time. The maximum parsimony networks as well as the haplotype diversities indicate high gene flow among the Atlantic populations, with the exception of the ones from the Gulf of Cádiz. It would be useful to confirm these assumptions with more individuals per population and more populations to cover the whole distribution area of $P$. serratus and to quantify gene flow statistically, as no populations east of Belgium and south of Spain are represented in this study.

Our results suggest the existence of a potential cryptic species or at least ongoing speciation within $P$. serratus, i.e. a morphological indistinct lineage separated by genetic differences at species level (Belfiore et al., 2003). The separation of the ML and the $\mathrm{AL}$ amounts to $2.0 \%$ in the $16 \mathrm{~S}$ gene and $10.14 \%$ in the Cox1 gene and is thus comparable to recognized species from other crustacean genera with an AtlanticMediterranean separation, such as in Carcinus (see Geller et al., 1997; Roman \& Palumbi, 2004; Ragionieri \& Schubart, 2013) or Brachynotus (see Schubart et al., 2001). Furthermore, the independently evolving nuclear gene Enolase confirms the same differentiation pattern. So far, there are no morphological characters known that differ in Atlantic and Mediterranean specimens of $P$. serratus, but this needs to be verified in a separate study. It would also be important to know if hybridization of Atlantic and Mediterranean individuals is possible. Considering the fact that in this study only a few populations were represented by more than 10 individuals, statistical possibilities are limited and make further studies with larger sample sizes necessary. No type locality for Palaemon serratus was indicated by Pennant (1777), but even though a few Mediterranean individuals were included in his first study characterizing the species, most of the individuals studied were from the Atlantic Ocean, i.e. from the English Channel, Belgium and the Netherlands (De Man, 1915). For that reason, and because Pennant published his results in British Zoology, it appears logical that the species name Palaemon serratus would remain with the Atlantic 
individuals, if two separate species were to be recognized in the future.

Overall, this study reveals some interesting phylogeographic aspects, although the results have limited conclusive significance, due to the restricted number of populations and the fact that some analysed populations consisted of very few individuals and therefore could not be used for statistical analyses. Hence, more research is needed regarding the population genetics and taxonomic status of $P$. serratus, including morphological and morphometric aspects, to understand the remarkable case of an Atlantic population with haplotypes that are more closely related to Mediterranean ones than to the other Atlantic ones, and to decide whether a cryptic species is involved.

\section{SUPPLEMENTARY MATERIAL}

To view supplementary material for this article, please visit https://doi.org/10.1017/So025315417000492

\section{ACKNDWLEDGEMENTS}

We would like to thank Cédric d'Udekem d'Acoz, Daniel Hamm, Carsten H.G. Müller, Piero Calosi, Henrik M. Schubart, Declan Quigley, Declan McGabhann and Hans De Blauwe for providing us with specimens of Palaemon serratus and for help during collecting. Also thanks to Sammy De Grave for museum specimens and specific literature and to Stefan Buchhauser for help with preparing the figures. One part of the work was carried out using the resources of the Departamento de Biología Celular y Molecular of the Universidade da Coruna, the other one in the Department of Zoology and Evolutionary Biology of the University of Regensburg (thanks to Prof. Jürgen Heinze).

\section{FINANCIAL SUPPORT}

This study was financed by the research funds of the Universidade da Coruña AGL2011-23689 and of the Universität Regensburg. EGO was funded by the Juan de la Cierva Research Program (MINECO) and Campus de Excelencia Internacional del Mar (CEIMAR).

\section{REFERENCES}

Ashelby A.C.W., De Grave S. and Johnson M.L. (2013) The globa invader Palaemon macrodactylus (Decapoda, Palaemonidae): an interrogation of records and a synthesis of data. Crustaceana 86, 594-624.

Belfiore N.M., Hoffmann F.G., Baker R.J. and Dewoody J.A. (2003) The use of nuclear and mitochondrial single nucleotide polymorphisms to identify cryptic species. Molecular Ecology 12, 2011-2017.

Bilgin R., Utkan M.A., Kalkan E., Karhan S.Ü. and Bekbolet M. (2014) DNA barcoding of twelve shrimp species (Crustacea: Decapoda) from Turkish seas reveals cryptic diversity. Mediterranean Marine Science $16,36-45$.

Carlisle D.B. (1955) Local variations in the colour pattern of the prawn Leander serratus (Pennant). Journal of the Marine Biological Association of the United Kingdom 34, 559-563.
Cartaxana A. (2015) Morphometric and molecular analyses for populations of Palaemon longirostris and Palaemon garciacidi (Crustacea, Palaemonidae): evidence for a single species. Estuarine Coastal Shelf Science 154, 194-204.

Carvalho F., De Grave S. and Mantelatto F.L. (2016) An integrative approach to the evolution of shrimps of the genus Palaemon (Decapoda, Palaemonidae). Zoologica Scripta. doi: 10.1111/zsc.12228.

Clement M., Posada D. and Crandall K.A. (2000) TCS: a computer program to estimate gene genealogies. Molecular Ecology 9, 16571660.

Costa F.O., de Waard J.R., Boutillier J., Ratnasingham S., Dooh R.T., Hajibabaei M. and Hebert P.D.N. (2007) Biological identifications through DNA barcodes: the case of the Crustacea. Canadian Journal of Fisheries and Aquatic Science 64, 272-295.

Crandall K.A. and Fitzpatrick J.E. (1996) Crayfish molecular systematic: using a combination of procedures to estimate phylogeny. Systematic Biology 45, 1-26.

Cuesta J.A., Drake P., Martínez-Rodríguez G., Rodríguez A. and Schubart C.D. (2012) Molecular phylogeny of the genera Palaemon and Palaemonetes (Decapoda, Caridea, Palaemonidae) from a European perspective. Crustaceana 85, 877-888.

De Grave S. and Ashelby A.C.W. (2013) A re-appraisal of the systematic status of selected genera in Palaemoninae (Crustacea: Decapoda: Palaemonidae). Zootaxa 3734, 331-344.

Deli T., Fratini S., Ragionieri L., Said K., Chatti N. and Schubart C.D. (2016) Phylogeography of the marbled crab Pachygrapsus marmoratus (Decapoda, Grapsidae) along part of the African Mediterranean coast reveals genetic homogeneity across the Siculo-Tunisian Strait versus heterogeneity across the Gibraltar Strait. Marine Biology Research 12, 5, 471-487. doi: 10.1080/17451000.2016.

De Man J.G. (1915) On some European species of the genus Leander Desm., also a contribution to the fauna of Dutch waters. Tijdschrift van de Nederlandse Dierkunde Vereniging 2, 115-179.

d'Udekem d'Acoz C. (1999) Inventaire et distribution des crustacés décapodes de l'Atlantique nord-oriental, de la Méditerranée et des eaux continentales adjacentes au nord de $25 \mathrm{~N}$. Collection patrimoines naturels $40,1-383$.

Fahy E., Forrest N., O’Toole M., Mortimer R. and Carroll J. (2006) Indicators of performance in the fishery for shrimp Palaemon serratus (Pennant) in Irish coastal waters. Journal of Shellfish Research 25, $1021-1026$.

Fratini S., Ragionieri L., Deli T., Harrer A., Marino I.A.M., Cannicci S., Zane L. and Schubart C.D. (2016) Unravelling population genetic structure with mitochondrial DNA in a notional panmictic coastal crab species: sample size makes the difference. BMC Evolutionary Biology 16, 150. doi: 10.1186/s12862-016-0720-2.

Galarza J.A., Carreras-Carbonell J., Macpherson E., Pascual M., Roques S., Turner G.F. and Rico C. (2009) The influence of oceanographic fronts and early-life-history traits on connectivity among littoral fish species. Proceedings of the National Academy of Sciences USA 106, $1473-1478$.

García-Castellanos D., Estrada F., Jiménez-Munt I., Gorini C., Fernàndez M., Vergés J. and De Vicente R. (2009) Catastrophic flood of the Mediterranean after the Messinian salinity crisis. Nature $462,778-781$.

García-Merchán V.H., Robainas-Barcia A., Abelló P., Macpherson E., Palero F., García-Rodríguez M., Gil de Sola L. and Pascual M. (2012) Phylogeographic patterns of decapod crustaceans at the Atlantic-Mediterranean transition. Molecular Phylogenetics and Evolution 62, 664-672. 
Geller J.B., Walton E.D., Grosholz E.D. and Ruiz G.M. (1997) Cryptic invasions of the crab Carcinus detected by molecular phylogeography. Molecular Ecology 6, 901-906.

González-Ortegón E. and Cuesta J.A. (2006) An illustrated key to species of Palaemon and Palaemonetes (Crustacea: Decapoda: Caridea) from European waters, including the alien species Palaemon macrodactylus. Journal of the Marine Biological Association of the United Kingdom 86, 93-102.

González-Ortegón E., Cuesta J.A. and Schubart C.D. (2007) First report of the oriental shrimp Palaemon macrodactylus Rathbun, 1902 (Decapoda, Caridea, Palaemonidae) from German waters. Helgoland Marine Research 61, 67-69.

González-Ortegón E., Baldó F., Arias A., Cuesta J.A., Fernández-Delgado C., Vilas C. and Drake P. (2015) Freshwater scarcity effects on the aquatic macrofauna of a European Mediterranean-climate estuary. Science of the Total Environment 503-504, 213-221.

González-Ortegón E. and Giménez L. (2014) Environmentally mediated phenotypic links and performance in larvae of a marine invertebrate. Marine Ecology Progress Series 502, 185- 195.

González-Ortegón E., Palero F., Lejeusne C., Drake P. and Cuesta J.A. (2016) A salt bath will keep you going? Euryhalinity tests and genetic structure of caridean shrimps from Iberian rivers. Science of the Total Environment 540, 11-19.

Haig J., Ryan N.M., Williams K.F. and Kaiser M.J. (2014) A review of the Palaemon serratus fishery: biology, ecology and management. Fisheries and Conservation Report. Bangor: Bangor University, 38 pp.

Hall T.A. (1999) BioEdit: a user-friendly biological sequence alignment editor and analysis program for Windows 95/98/NT. Nucleic Acids Symposium Series 41, 95-98.

Hofrichter A.A. (2002) Das Mittelmeer - Fauna, Flora, Ökologie Band I. Heidelberg: Spektrum Akademischer Verlag.

Hsü K.J., Montadert L., Bernoulli D., Cita M.B., Erickson A., Garrison R.E., Kidd R.B., Mèlierés F., Müller C. and Wright R. (1977) History of the Mediterranean salinity crisis. Nature 267, 399-403.

Ip B.H.Y., Schubart C.D., Tsang L.M. and Chu K.H. (2015) Phylogeny of the shore crab family Grapsidae (Decapoda: Brachyura: Thoracotremata) based on a multilocus approach. Zoological Journal of the Linnean Society 174, 217-227.

Kingman J.F.C. (1982) On the genealogy of large populations. Journal of Applied Probability 19A, 27-43.

Krijgsman W., Hilgen F.J., Raffi I., Sierro F.J. and Wilson D.S. (1999) Chronology, causes and progression of the Messinian salinity crisis. Nature 400, 652-655.

Lagardère J.P. (1971) Les crevettes des côtes du Maroc. Travaux de l'Institut Scientifique Chérifien 36, 1-140.

Lefébure T., Douady C.J., Gouy M. and Gibert J. (2006) Relationship between morphological taxonomy and molecular divergence within Crustacea: proposal of a molecular threshold to help species delimitation. Molecular Phylogenetics and Evolution 40, 435-447.

Librado P. and Rozas J. (2009) DnaSP v5: a software for comprehensive analysis of DNA polymorphism data. Bioinformatics 25, 1451-1452.

Luttikhuizen P.C., van Bleijswijk J.C.J., Peijnenburg K.T.C.A. and van der Veer H.W. (2008) Phylogeography of the common shrimp Crangon crangon (L.) across its distribution range. Molecular Phylogenetics and Evolution 46, 1015-1030.

Mathews L.M. (2006) Cryptic biodiversity and phylogeographic patterns in a snapping shrimp complex. Molecular Ecology 15, 4049-4063.
Patarnello T., Volckaert F. and Castilho R. (2007) Pillars of Hercules: is the Atlantic-Mediterranean transition a phylogeographical break? Molecular Ecology 16, 4426-4444.

Pennant T. (1777) Crustacea Mollusca Testacea. British Zoology 4, London, 1-157; plates 1-93.

Ragionieri L., Fratini S., Vannini M. and Schubart C.D. (2009) Phylogenetic and morphometric differentiation reveal geographic radiation and pseudo-cryptic speciation in a mangrove crab from the Indo-West Pacific. Molecular Phylogenetics and Evolution 52, $825-834$.

Ragionieri L. and Schubart C.D. (2013) Population genetics, gene flow, and biogeographical boundaries of Carcinus aestuarii (Crustacea: Brachyura: Carcinidae) along the European Mediterranean coast. Biological Journal of the Linnean Society 109, 771-790.

Reeve M.R. (1968) The suitability of the English prawn Palaemon serratus (Pennant) for cultivation - a preliminary assessment. In Proceedings of the world scientific conference on the biology and culture of shrimps and prawns. Vol. 3. Conway, North Wales: Fisheries and Aquaculture Department.

Reeve M.R. (1969) Growth, metamorphosis and energy conversion in the larvae of the prawn, Palaemon serratus. Journal of the Marine Biological Association of the United Kingdom 49, 77-96.

Remerie T., Vierstraete A., Weekers P.H.H., Vanfleteren J.R. and Vanreusel A. (2009) Phylogeography of an estuarine mysid, Neomysis integer (Crustacea, Mysida), along the north-east Atlantic coasts. Journal of Biogeography 36, 39-54.

Reuschel S., Cuesta J.A. and Schubart C.D. (2010) Marine biogeographic boundaries and human introduction along the European coast revealed by phylogeography of the prawn Palaemon elegans. Molecular Phylogenetics and Evolution 55, 765-775.

Ríos C., Sanz S., Saavedra C. and Peña J.B. (2002) Allozyme variation in populations of scallops, Pecten jacobaeus (L.) and P. maximus (L.) (Bivalvia: Pectinidae), across the Almeria-Oran front. Journal of Experimental Marine Biology and Ecology 267, 223-244.

Rodríguez A. (1981) Growth and sexual maturation of Penaeus kerathurus (Forskäl, 1775) and Palaemon serratus (Pennant) in salt ponds. Aquaculture 24, 257-266.

Roman J. and Palumbi S.R. (2004) A global invader at home: population structure of the green crab, Carcinus maenas, in Europe. Molecular Ecology 13, 2891-2898.

Schubart C.D. (2009) Mitochondrial DNA and decapod phylogenies: the importance of pseudogenes and primer optimization. In Martin J.W., Crandall K.A. and Felder D.L. (eds) Decapod Crustacean phylogenetics. Crustacean Issues. Boca Raton, Florida: Taylor \& Francis/CRC Press. $18,47-65$

Schubart C.D., Cuesta J.A. and Rodríguez A. (2001) Molecular phylogeny of the crab genus Brachynotus (Brachyura: Varunidae) based on the $16 \mathrm{~S}$ rRNA gene. Hydrobiologia 449, 41-46.

Schubart C.D., Neigel J.E. and Felder D.L. (2000) The use of the mitochondrial 16S rRNA gene for phylogenetic and biogeographic studies of Crustacea. In The biodiversity crisis and Crustacea. Proceedings of the Fourth International Crustacean Congress. Amsterdam, 20-24 July 1998, Vol. 2. Crustacean Issues 12, 817-830.

Thompson J.D., Higgins D.G. and Gibson T.J. (1994) CLUSTAL W: improving the sensitivity of progressive multiple sequence alignment through sequence weighting, position-specific gap penalties and weight matrix choice. Nucleic Acids Research 22, 4673-4680.

Tintoré J., La Violette P., Blade I. and Cruzado A. (1988) A study of an intense density front in the eastern Alboran Sea: the Almeria-Oran Front. Journal of Physical Oceanography 18, 1284-1397. 
Tsang L.M., Schubart C.D., Ahyong S.T., Lai J.C.Y., Au E.Y.C., Chan T., Ng P.K.L. and Chu K.H. (2014) Evolutionary history of true crabs (Crustacea: Decapoda: Brachyura) and the origin of freshwater crabs. Molecular Biology and Evolution 31, 1173-1187.

and

Zane L., Ostellari L., Maccatrozzo L., Bargelloni L., Cuzin-Roudy J., Buchholz F. and Patarnello T. (2000) Genetic differentiation in pelagic crustacean (Meganyctiphanes norvegica: Euphausiacea) from the North Atlantic and the Mediterranean Sea. Marine Biology 136, $191-199$.

\section{Correspondence should be addressed to:}

C. D. Schubart

Zoologie \& Evolutionsbiologie,

Universität Regensburg,

D-93040 Regensburg, Germany.

email: Christoph.Schubart@ur.de 